\title{
Asetabuler komponent tasarım ve uygulama teknikleri
}

\section{Design and application techniques of acetabular components}

\author{
M. Sadık Bilgen, A. Özdel, Ö. Faruk Bilgen \\ Uludağ Üniversitesi Tıp Fakültesi, Ortopedi ve Travmatoloji Anabilim Dalı, Bursa
}

Total eklem protezleri, sadece ortopedide değil, tüm tıptaki devrim niteliğindeki süreçlerden biri olarak kabul edilir. Sağlık hizmetlerindeki iyileşmelerden dolayı protez uygulanmış hastalar daha uzun yaşamakta ve revizyon ihtiyacı artmaktadır. Komponent tasarımı ve kullanılan alaşımlarda yapılan iyileştirmelerle, daha genç ve aktif hasta grubunun doğurduğu yüksek beklentiler karşılanmaya çalışılmaktadır. En gelişmiş implantlarla yapılan bir uygulamanın bile uygun biyomekanik ve cerrahi teknikle yapılması gerektiği akıldan çıkarılmamalıdır. Hastanın ihtiyacına göre, sağlamlık ve esneklik arasında belli bir denge sağlanmalıdır. En yeni implant modelleri her hasta için en ideal çözüm olmayabilir. Kalça protezinde, özellikle asetabuler komponentin tercihinde, uygun endikasyon ve uygun materyal seçimi en önemli konudur. Günümüzde, 65 yaş üstü, kemik stoğu iyi olmayan ve aktivite düzeyi düşük olan hastalarda genel olarak çimentolu protezler tercih edilirken, genç ve aktif hastalarda daha çok çimentosuz komponentler tercih edilmektedir. Yeni modellerin tasarımları, sürtünme ve aşınmayı azaltmayı hedeflemektedir. Kemik-implant bütünleşmesini arttırmak için, kemik gelişimini tetikleyen gözenekli metaller kullanılmaya başlanmıştır. Bu yazıda, iyi bir tespit, düşük aşınma yeterli stabilite ve yüksek hareket açıklığı elde edebilmek için ideal asetabuler komponent seçenekleri üzerine durulmaktadır.

Anahtar sözcülkler: kemik çimentosu; yüzey özellikleri
Total joint replacement is accepted as one of the most revolutionary procedures not just in orthopedics, but in whole medicine. With better healthcare, patients with replaced joints live longer, which causes more surgical revisions. Advances in both component design and material composition try to fulfill the increasing demand of younger and more active patient population. It should be remembered that even the most advanced component should be applied with proper biomechanical and surgical techniques. A balance between implant stiffness and flexibility must be obtained according to patient's expectations. Newer and more advanced designs need not be the ideal choice for every patient. Proper indication and convenient material choice are the most important issues in total hip arthroplasty, especially in the selection of acetabular component. Nowadays, cementation is mainly used in patients above 65 years of age with compromised bone quality, while on the other hand uncemented prostheses are preferred for younger and more active patients with good bone quality. New component designs aim lower friction and decrease of wear. New porous materials stimulating bone ingrowth are introduced to enhance bone-implant integration. This paper focuses on ideal acetabular component designs and new advances to achieve good fixation, low wear on bearing surfaces, adequate stability and high range of motion.

Key words: bone cements; surface properties
K alça eklemi, insan vücudunun en fazla yüke maruz kalan ve bunun sonucunda da fazla miktarda aşınmaya uğrayan ve ciddi yakınmalara neden olan eklemidir. Doğuştan kalça çıkığı, Perthes, romatoid artrit ve avasküler nekroz gibi nedenlerden başka sosyoekonomik gelişmeye paralel olarak, trafik kazaları ve iş kazalarındaki artma ile birlikte kalça ekleminde dejeneratif artrite eğilim de artış göstermektedir. ${ }^{[1]}$ Kalçayı etkileyen yük dağılımını dengelemek ve ağrıyı ortadan kaldırmaya yönelik tasarlanan osteotomiler, rezeksiyon artroplastileri ve kalça artrodezi gibi yöntemler gerekli durumlarda halen kullanım alanı bulmaktadır. ${ }^{[1]}$ Bununla birlikte günümüzde total kalça artroplastisi, sorunun çözümü için esas yol ve yöntem olarak uygulanmaktadır. Total kalça protezi (TKP) uygulamasında amaç; ağrıyı gidermek ve fonksiyonları arttırmaktır. Doğru endikasyonlar içerisinde uygulanan başarılı cerrahi teknik, TKP uygulamalarında iyi ve mükemmel sonuçlar elde edilmesinde esastır. Bununla birlikte uygun materyal ve tasarım özeliklerine

- İletişim adresi: Dr. M. Sadık Bilgen, Uludağ Üniversitesi Tıp Fakültesi Hastanesi, Ortopedi ve Travmatoloji Anabilim Dalı, Özlüce Mh. 16120 Bursa Tel: 0532 - 2120343 e-posta: msbilgen@superonline.com

- Geliștarihi: 27 Mart 2013 Kabul tarihi: 16 Temmuz 2013 
sahip implant kullanılması da TKP uygulamalarında başarıyı arttırır. Günümüzde farklı materyal ve tasarım özeliklerine sahip birçok protez geliştirilmiştir. Seçilen implantın tasarımı ve materyal özellikleri, protezin basit, üretilebilir, ucuz, güvenilir ve uzun ömürlü olmasını sağlamalıdır; cerraha yeterince seçenek sunabilmeli ve teknik zorluk çıkarmamalıdır. Uygulama sırasında mümkün olduğunca az kemik rezeksiyonu gerektirmelidir.

Kurtz ve arkadaşlarının ${ }^{[2]}$ ulusal istatistik enstitüsü verilerine dayanarak yaptıkları 2011 yılı tahminlerinde, tüm artroplastilerin \% 50'den fazlasının 65 yaş altı hastalara uygulanacağı hesaplanmıştır. 2030 yılında ise genç hastaların TKP olgularının \% 52'sini oluşturacağı öngörülmüştür. Bu rakamlar daha genç ve beklentisi daha yüksek bir hasta grubuyla karşılaşılacağını ve uzun ömürlü implant üretimi için protez tasarımı ve implant özelliklerine her zamankinden daha fazla önem verilmesi gerektiğini göstermektedir. İmplantlar, ideal bir protez stres kalkanı oluşumunu önleyecek kadar esnek, primer stabilite sağlayacak kadar da sert olmalıdır. Komponentin yüzey kaplaması kemikle temas sonrası aşınmayacak dayanıkıııkta olmalıdır. Modüler komponentler optimal uyum ve primer stabiliteyi aynı anda sağlamalı ve cerrahi tekniğe uygun olmalıdır. Protez uygulamalarında en önemli başarısızlık nedeni osteoliz, enfeksiyon ve çıkıktır. Bu komplikasyonlar, cerrahi tekniğe ve implant seçimine dikkat edilmesi ile azaltılabilir.

\section{TARIHÇE}

Kalça artroplastisinde amaç, bozulmuş ve ankiloze olmuş eklem yüzünün düzeltilmesi ve her iki eklem yüzü arasına konulacak materyaller ile ekleme ağrısız hareket fonksiyonu kazandırılmasıdır. İlk olarak 1840 yılında, genel cerrah olan Carnochan tarafindan bir ağaç parçası (şimşir ağacı) kullanılarak mandibula boynu eksizyonu üzerine interpozisyonel artroplasti uygulanmıştır. 1860 yılında Verneuil, interpozisyon amacı ile kas ve fasya kullanmıştır. 1890'da Lexer ve Payi, tensor fasya lata kasını kullanırken, Loewe bu amaçla cilt kullanmıştır. 1912'de Sir Robert Jones, araya giren tabaka olarak altın yapraklarını kullanmışsa da, bu yöntem kalıcı ağrı ve eklem sertliğine yol açtığından başarısız olmuştur. ${ }^{[3]} 1917$ yilında Willam S. Baer, ara membran olarak domuz mesanesinden yapılan yaprakları kullanmıştı. ${ }^{[1]}$ Helsinki'de Kallio, başarılı bir şekilde, cildin dermal tabakalarını ara membran olarak kalça artroplastisi yapılan hastalarda kullanmıştır. ${ }^{[4]} 1923$ yılında Smith-Petersen, alternatif bir yöntem olarak "kalıp artroplastisi” kavramını bildirmiştir. Bu yöntemin amacı, uyumlu eklem yüzü elde etmek için femur başı ve asetabulum kansellöz kemiğinde kanamaya yol açarak, fibrin pıhtılarının fibrokartilaj dokuya metaplazisini sağlamaktır. Kalıp materyali olarak ilk önce cam kullanılmıştır. Smith Petersen, bu camı çevreleyen sinovyal bir zar olduğunu gözlemlemiştir. Yerleştirilen cam materyaller birkaç ay içinde kırılmış olsa da, sonuçların ümit verici olması, daha dayanıklı materyallerin geliştirilmesini teşvik etmiştir. Ateşe dayanıklı cam (pyrex), kolloid deriveleri ve bakalit gibi maddeler de kırılganlık ve yabancı cisim reaksiyonlarına yol açmaları nedeniyle kabul görmemiştir. Venable ve Stuck tarafindan 1937'de keşfedilen vitalyum sayesinde, yeterli dayanıklılıkta materyal bulma olanağı doğmuştur. ${ }^{[5,6,7]}$ 1917'de Brackett ve 1921'de Whitman, rekonstürktif artroplastiyi tanımlamıştır; Magnuson, Colonna, Luck ve Wilson ise bu süreci geliştirmişlerdir. 1921'de Sir Robert Jones, "Jones psödoartrozu” olarak bilinen girişimini ve 1945 'de ise Girdlestone, rezeksiyon artroplastilerini tanımlamışlardır. Tüm bu girişimler, sonuçta hareketli bir kalça eklemi elde etmeye yönelikti. Charnley ise, uygulamış olduğu santral dislokasyonstabilizasyon yöntemi ile ağrısız ve hareketli bir kalça eklemi elde etmeyi amaçlamıştı. ${ }^{[8]}$

Femur başı protez tasarımlarında gelişmelerin olmaSı, parçaların üretiminde kullanılan maddelerin daha dayanıklı ve uygun hale gelmesi, üretim tekniklerinin iyileştirilmesi, kalça biyomekaniğinin daha iyi anlaşılması ve asetabulum eklem yüzeyinin yeniden düzenlenme anlayışııın gelişmesi ile, total kalça artroplastisi alanında önemli gelişmeler kaydedilmiştir. İlk kısmi replasman artroplasti denemeleri 1919 yılında Delbet tarafından kauçuk kullanılarak ve 1927 yılında Graves tarafından fildişi kullanılarak yapılmıştır. Başarısızlıkla sonuçlanan bu denemelerden sonra, ilk başarılı metalik replasman artroplastisi 1940 yılında Bohlman ve Moore tarafından paslanmaz çelikten yapılmış protez kullanılarak gerçekleştirilmiştir. ${ }^{[9,10]} 1948$ yılında Judet kardeşler, metil metakrilattan yaptıkları bir protezi uygulamaya başladılar. Bu protez o zamanlar yaygın bir biçimde kabul görmüş olduğu halde, kontrollerde geniş oranda gevşeme ve kırılma görülmesi nedeniyle popülaritesini kaybetti. Ancak yine de, plastik materyallerin insan vücudu tarafından tolere edilebileceğini gösterdiği için anlamlı bir çalışmaydı. ${ }^{[11]}$ Femur başı ve asetabulumu fildişinden yaparak, bunları alçı, reçine ve süngertaşı karışımından yapılma bir çimento ile tespit eden Gluck, 1890 yılında total kalça replasmanı anlayışını getiren ilk cerrahtır. Ancak Pean'e göre fildişi tasarımı çok çabuk bozulmaya uğramaktaydı. 1938 yılında, paslanmaz çelikten yaptığı asetabuler komponenti vida ve plak ile, femoral komponenti de femur boynuna vida ile tespit eden Philip Wiles, metal kalça replasmanını ilk uygulayan kişi olarak kabul edilir. Ancak Wiles'ın bu şekilde ameliyat etmiş olduğu altı hastada sonuçlar memnun edici olmamıştı. ${ }^{[8,12]}$ 
Total kalça replasmanının kullanışlı bir işlem olduğunu ilk saptayan John Charnley'dir. Ayrıca, dünyanın herhangi bir yerinde, iyi eğitilmiş ortopedik cerrahlar tarafindan yapılabilirliğini ortaya koymuştur. Yük binen yüzeyde politetrafloretilen (teflon) kullanımındaki ilk başarısızlık sonrası Charnley, yüksek molekül ağırlıklı polietileni uygulamış ve başarı elde etmiştir. ${ }^{[13]}$ Charnley'in önemli bir katkısı da implantların sabitlenmesi için akrilik çimentosu (polimetilmetakrilat) kullanmasıdır. Politetrafloretilen maddesinin aşırı doku reaksiyonuna yol açtığını ve süratle aşındığını görüp, asetabulum için önceleri yüksek yoğunluklu polietilen (High Density Polyethylene-HDPE) kullanmışsa da, daha sonra ultra yüksek molekül ağırlıkı polietilen (Ultra High Molecule Weighted Polyethylene-UHMWPE) kullanmaya başlamıştır. Daha sonra polimetilmetakrilat ile femoral implantı medulla içine, asetabuler plastik kabı da asetabuluma sabitlemiştir. Dolayısıyla yükün daha geniş bir yüzeye eşit olarak dağılmasını sağlamayı hedeflemiştir. Ayrıca Moore protezinde $40 \mathrm{~mm}$ olan femur başı çapını 22 mm'ye indirmiştir. Böylece, sürtünme kurveti kaldıraç kolunu azaltmayı ve hareketteki zorlanmayı gidermeyi amaçlamıştır. ${ }^{[14,15]}$

Poroz kaplı ve paslanmaz çelikten imal edilmiş olan protezler ilk olarak Tronzo tarafından, 1960'lı yılların sonu ve 1970 'li yılların başlarında ise Avrupa'da Judet, Lord ve diğer bazı araştırmacılar tarafindan uygulanmaya başlanmıştır. Ancak biyolojik tespit terimi ilk olarak 1950'lerde Austin Moore tarafindan ortaya atılmıştır. ${ }^{[14]}$ Bu sırada Rayan, gözenekli kobalt-krom kaplı protezleri uygulamaya başlamıştır. Yine 1980'lerin ortalarında Furlong ve Osborne, hidroksiapatit kaplı implantlar ile klinik çalışmalar yapmıştır. Amerika Birleşik Devletleri'nde, Food and Drug Administration (FDA) tarafından onaylanması ile birlikte, 1988 yılında yayımlanan ileriye dönük, çok merkezli bir çalışma ile hidroksiapatit kaplı femoral komponentlerin etkinliği araştırılmaya başlanmıştır. ${ }^{[16,17]}$ Türkiye'de total kalça artroplastisi ilk uygulayıcılarından birisi de Ankara Üniversitesi Tıp Fakültesi Ortopedi ve Travmatoloji Kliniği'dir. ${ }^{[11]}$

\section{ASETABULER KOMPONENTLERIN ÖZELLIKLERI VE KAP TASARIMLARI}

Her yıl dünya çapında bir milyon kişi kalça protez ameliyatı geçirmektedir. Travma ya da ciddi kalça patolojilerine bağlı kalça eklem ağrısı geçiren hastalarda başarılı ve güvenilir bir yöntem olan kalça protezi uygulamaları, ağrısız kalça ekleminin oluşturulmasında ve fonksiyonel bir kalça ekleminin yeniden sağlanmasında etkilidir. Bu amaçla, başlangıçta çimentolu ve daha sonra teknolojik ilerlemeler sonucunda geliştirilen çimentosuz ve hibrid sistem total kalça artroplastisi uygulamaları yaygın olarak yapılmaktadır.

Asetabulum superior bölümü dairesel sınıra sahip olup femur başının $170^{\circ}$ 'lik kısmını örtecek şekilde hemisferik derinliğe sahiptir. Asetabulumu iki güçlü kemik kolon çevreler ve bu kolonlar gövde ile alt ekstremiteler arasındaki yükleri iletir. Asetabulum çevresinden geçerken bu kolonların kalınlıkları değişir. Asetabulumun kenarı yük verildiğinde kapanır ve femur başına temas eder. Bu hareketin derecesi yaşa, etkileyen yüke, femur anteversiyonuna bağlı olarak değişir. Genç hastalarda asetabuler kenarın daha hareketli olmasının, bu olgularda TKP uygulaması sonrası daha sık meydana gelen asetabuler komponentte aseptik gevşemenin bir nedeni olabileceği düşünülmüştür.

TKP uygulamalarında komponentlerin başlangıç stabilitesi, başarılı sonuç elde edilmesinde esastır. Bunun sağlanması amacıyla geliştirilen farklı materyal ve tasarımdaki asetabuler komponentlerin avantaj ve dezavantajları vardır. Başlangıç stabilitesi, komponentin tasarımına, büyüklüğüne, uygulanan cerrahi tekniğe bağlıdır. Çimentolu uygulamalarda kemik-çimento arasındaki stabilite çimentonun kemiğe tutunması ile çok yakından ilgilidir. Çimentosuz uygulamalarda ise kemik-komponent arasındaki yeterli başlangıç stabilitesi kemiğin komponente entegrasyonu ile biyolojik stabiliteye dönüşür.

\section{ÇIMENTOLU ASETABULER KOMPONENT}

Kemik kalitesi kötü olan yaşlılarda, osteoporozlu veya kronik enflamatuar hastalıklı olgularda, TKP uygularken kemik çimentosu kullanımı optimal primer stabiliteyi temin eder. Fakat kemik çimentosunun mekanik ve biyolojik yönden kısıtlı olduğu unutulmamalıdır. Çimento, kemik implant yüzeyleri arasında yapışkan bağlantı oluşturmaz, boşluk doldurucu görevi yapar. Isınan çimentonun yarattığı nekrotik kemik dokusu, osteoklastik emilim ile uzaklaştırılır ve yeni kemik dokusu daha önce bulunmadığı yerlerde şekillenir.

Çimentolu komponentlerde erken dönemde güvenilir sonuçlar alınmış olsa da, uzun dönem çalışmalar sonucunda radyografik ve klinik gevşeme gözlenmiş ve revizyon ameliyat gerekliliği görülmüştür. Ayrıca çimentolu polietilen kabın yerleştirilmesi aşamasın$\mathrm{da}$, tecrübeli cerrahların bile zorlandığı sorunlarla (tamamen kansız bir alanın elde edilememesi ve optimum çimento basısı sağlayamama) karşılaşılmıştır. Çimentolu asetabuler komponent tasarımındaki ve çimentolama tekniklerindeki gelişmelere rağmen, bu tür komponentlerin kullanım endikasyonları giderek yaşlı ve beklentilerin düşük olduğu olgularla sınırı kalmaktadır. Çimentolu asetabuler komponent, çok yüksek 
yoğunluklu kalın polietilen ile kaplıdır. Ayrıca, yüzeyi arttırmak ve çimentoyla kilitlenmesini kolaylaştırmak için komponentin arka yüzeyinde $3 \mathrm{~mm}$ yükseklikte periferik çıkıntılar ile uygun derinlikte ve genişlikte birbirlerine dik oluklar yapılmıştır (Şekil 1). ${ }^{[18]}$ Bu çıkıntılar ile, vertikal ve horizontal oluklara çimento dolması sayesinde, düzgün bir çimento dağılımı sağlanarak kötü veya ince çimentolamanın engellenmesi ile stabilite arttırılmıştır. Ameliyat sonrası grafilerde, kabın yerinin belirlenmesi, inklinasyon ve anteversiyon açılarının kontrolü için, kapların kenarlarına tel yerleştirilmiştir.

Charnley, ilk TKP uygulamalarında düşük sürtünme katsayısına sahip olan teflonu asetabuler komponent için kullanmıştır; ancak, aşınma oranının beklenenden yüksek olması nedeniyle, 1962 yılında yüksek dansiteli -sürtünme katsayısı teflona göre beş kat daha yüksek olmasının yanı sıra aşınmaya 500-1000 kat daha dayanıklı olan- polietilen komponenti geliştirmiştir. illk uygulamalarda yüksek başarılı sonuçlar elde edilmesine karşın, uzun dönem izlemlerde \%2460 oranında gevşeme bildirilmiştir. ${ }^{[19,20,21]}$ Çimentolu asetabuler komponent uygulaması sonrası, asetabulum medial duvarı ve superior kansellöz kemikte kompresif kuvvetler, periferik subkondral kemikte ise tensil kuvvetler artar. Bu olumsuzlukları önlemek amacıyla, daha rijit komponent uygulamasının gelen stresleri çevre dokuya dağıtıp çimento ve subkondral kemikte yorgunluğa bağlı gelişen yetmezliği engelleyebileceği düşünülerek, çimentolu asetabuler komponentlerin arka yüzeyine metal arkalık eklenmiştir. Bu metal kaplamanın öncelikli amacı, yıpranmış polietileni kemik çimento integrasyonunu bozmadan değiştirmektir. ${ }^{[23]}$ Sonlu elemanlar (finite element) yöntemiyle, metal kaplamalı kaplarda daha sıkı polietilen tutunması sağlandığı ve daha iyi stres dağılımı

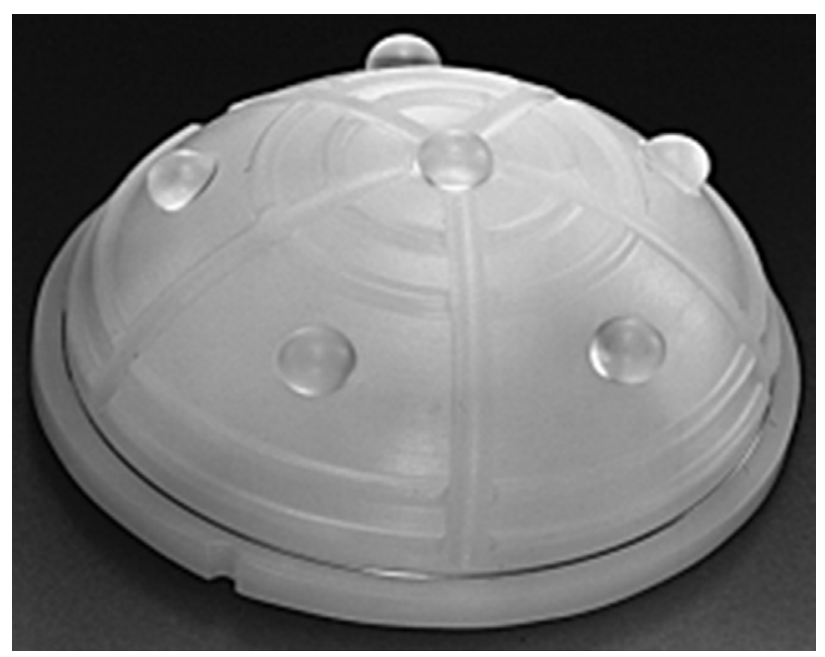

Şekil 1. Çimentolu asetabuler komponent. olduğu gösterilmiştir. Kısa dönem sonuçların iyi olmasına rağmen, 10 yıllık takiplerinde yıpranma miktarının daha fazla olduğu görülmüştürr. ${ }^{[22]}$ Çimentolu asetabuler kabın sağ kalım süresini çimentolu kabın tasarımı kadar kadar çimentolama tekniği de belirler. Ranawat ve ark. ${ }^{[23]}$ bu konu ile ilgili yaptıkları çalışmada, eski kuşak çimentolama tekniği ile 10 yıl içinde \%14 oranında gevşeme belirtirken, modern çimentolama teknikleri kullanarak 5 yıllık takiplerinde mükemmel sonuçlar elde etmişlerdir. Mulroy ve ark. ${ }^{[24]}$ yaptıkları diğer bir çalışmada, ikinci ve üçüncü kuşak çimentolama teknikleriyle femoral taraftaki aseptik gevşeme azaltılmış olsa da, asetabuler taraftaki aseptik gevşemenin azaltılması üzerine önemli bir etkisi olmadığı belirtilmişlerdir. Aynı çalışmada, çimentolu asetabuler komponentlerin 18-30 yıllık takiplerinde \%3-23 oranında başarısızlık ve \%15-54 oranında radyolojik gevşeme saptanmıştır.

Tüm bu çalışmalar sonucunda, çimentosuz asetabuler komponentler genç, aktif, yaşam beklentisi fazla olan hastalara önerilirken, çimentolu asetabuler komponentler, yaşı, kemik kalitesinin düşük, beklentileri az olan, ayrıca tümör rezeksiyonu veya revizyon ameliyatları geçirmiş, sedanter yaşam süren hastalara önerilmektedir.

Günümüzde geliştirilen daha yüksek dansiteli polietilenler (UHMWPE), çimentolu asetabuler komponentler için önerilen implantlardır. Etilenin yarı kristalize edilmiş polimer şekli olan polietilene, karbon iplikçikleri eklenip ısı ve basınç uygulanarak kristalizasyon arttırılır ve böylece aşınmaya daha dayanıklı olan polietilen (UHWMPE) elde edilir. ${ }^{[25]}$ Son zamanlarda radyasyon ve termal işlemlerle polietilenin dansitesi, çapraz (cross-linked) bağların sayısı ve dayanıklılığı daha da artırılmıştır (Şekil 2). ${ }^{[26]}$

Işınlama ile oluşan serbest radikaller eritme yöntemi ile yok edilebilmekte fakat erime sonrası yorgunluk direnci azalmaktadır. Çapraz bağ oluşturma işlemi sonrası ara parça kırılganlığının da artması, çatlak ve kırık oluşma riskini arttırmaktadır. Eritme yöntemi yerine ısıtmanın kullanılması kırılganlığı azaltmakta ve eritme kadar olmasa da serbest radikalleri uzaklaştırmaktadır.

Çimentolu protez uygulamalarında tespit stabilitesi, komponentin yerleştirildiği anda en yüksektir. Polietilen yüzeyini arttırarak, komponentin çimento ile temas alanı genişletilir ve böylece torsiyonel kuvvetlere karşı implant daha dirençli hale getirilir. İyi bir teknikle uygulanan çimentonun kansellöz kemiğe yeterince penetrasyonunun temini, uzun dönem sonuçları etkiler. Bunun sağlanması için, çimentonun yeterli basınç ile uygulanması gereklidir. Basıncı arttırmak için çevresi kenarlıklı (flange) komponentler geliştirilmiştir. 

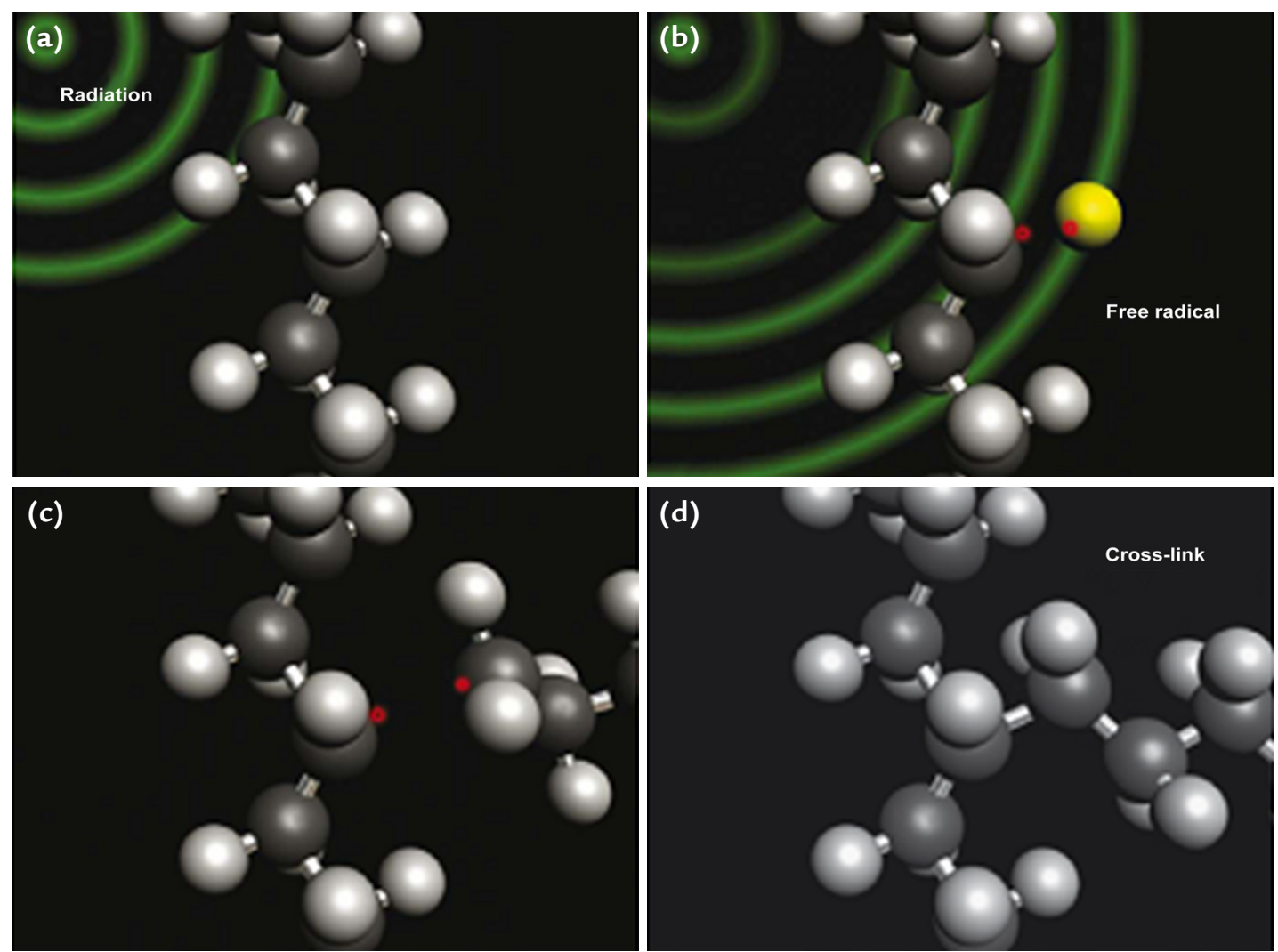

Şekil 2. Radyasyon ile polietilendeki çapraz bağların arttırılması: Polietilen moleküllerinin radyasyona maruz bırakılır (a). Radyasyon polietilen molekülü üzerinde hidrojen radikali (serbest radikal) oluşturur (b). Serbest radikallerin hareketliliği komşu moleküller tarafından sınırlanır. Bu daha büyük moleküle "makroradikal” denir (c). Komşu radikaller reaksiyona girerek kovalent bağlar oluşur ve iki polimer molekülü arasında çapraz bağ oluşur (d). ${ }^{[26]}$

Çimentolu asetabuler komponent uygulamalarında, yukarıda değindiğimiz materyal ve tasarım özelliklerine yeterli özen gösterilmediğinde, orta ve uzun dönemde istenen sonuçlar elde edilememektedir. Kavanough, ${ }^{[27]}$ 15 yıl izlemi olan 333 kalçada uygulanan çimentolu geleneksel PE asetabuler komponentlerin \%14'ünde revizyon ya da migrasyon, \%50'sinde global ışıngeçirgenliği tespit ettiğini bildirmiştir. Ritter, ${ }^{[28]} 238$ kalçanın 5,2 yıl izleminde metal arkalıklı polietilen komponentlerin \%39'unda, polietilen asetabuler komponentlerin ise \%23'ünde çimento-kemik yüzeyinde tam ışın-geçirgenliği tespit etmiştir.

\section{Cerrahi teknik}

Cerrahi yumuşak doku çıkarılarak asetabuluma ulaştıktan sonra, kemik hazırlığı için, pubis ve iskial kemiklerin pelvisle birleşme noktası olan anterior ve posterior kolonda kansellöz kanama görülene kadar, kademeli olarak oyma işlemi uygulanır. Çimentosuz asetabulum implantasyonundan farklı olarak, medial kansellöz kemiği korumak için çok fazla medializasyon önerilmez. Deneme, hazırlanan asetabuluma yerleştirilerek yönü en uygun duruma getirilir $\left(35-40^{\circ} \mathrm{ab}-\right.$ duksiyon ve $15-30$ derece $^{\circ}$ anteversiyon/ fleksiyon). Konulacak çimentonun dağılımının kontrolü için, denemenin iki parmağımız arasında rahatça dönebildiğini görmek gereklidir. Posterior kolonun kansellöz kemiği olan üst duvara birçok tespit delikleri açılır. Pübik ve iskial parçalarda da 2 adet büyük oyuk oluşturulur (Şekil 3). Pulsatil yıkama ile asetabulum temizlenir ve kemik yatak kuru gazlı bez ile kurutulur. Çimento kansellöz kemik üzerine uygulanır. Gözyaşı figürünün altındaki fazla çimento, komponentin öncelikle yerleştiği yer olması nedeniyle, dikkatlice temizlenir (Şekil 4). ${ }^{[1]}$

\section{Çimentolama teknikleri}

Kalça replasman cerrahisinde çimento tespiti, çimentonun kemiğe optimal interdigitasyonunun sağlanması için iyi bir cerrahi teknik gerektirir. Çimentolu TKP'de gevşeme nedeniyle ilk bozulan genellikle asetabuler 


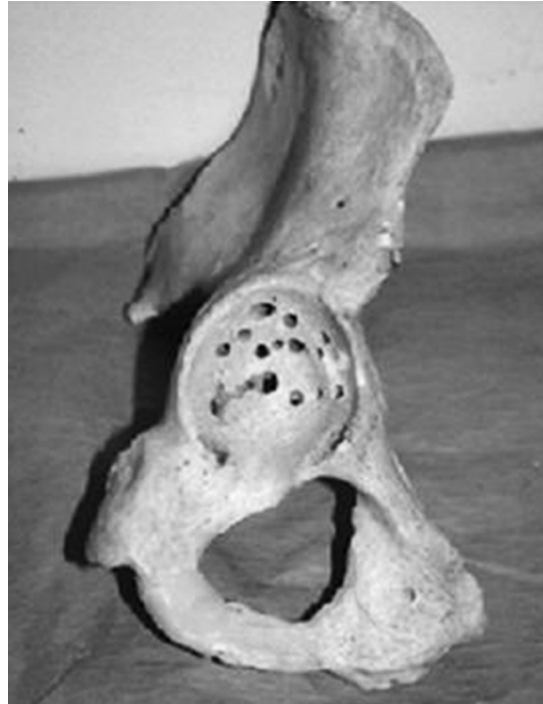

Şekil 3. Çimentolu protez uygulaması öncesi asetabulum hazırlığı.

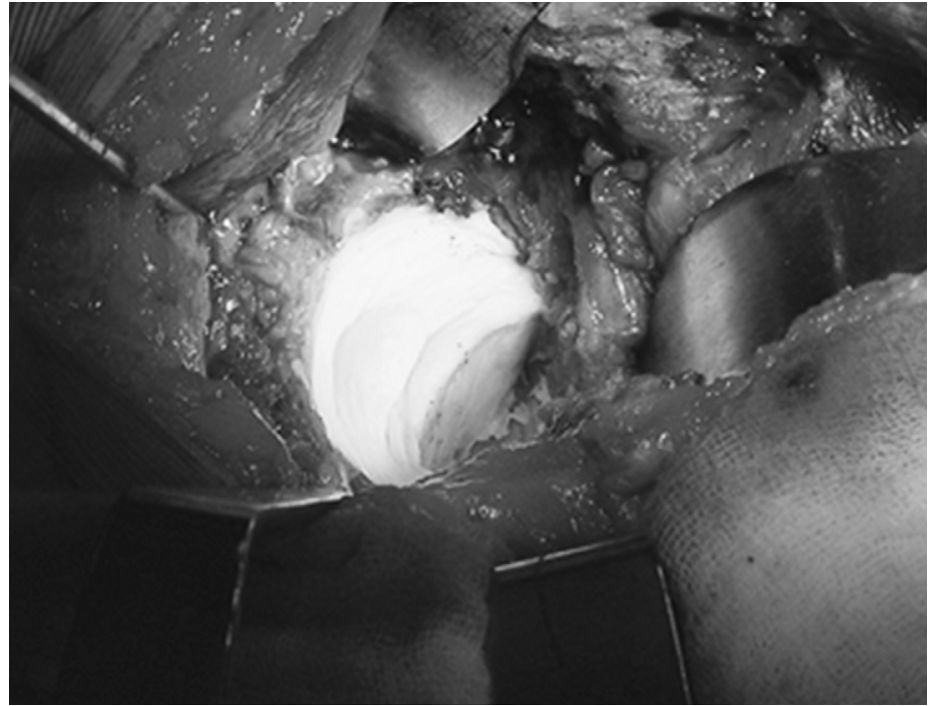

Şekil 4. Gözyaşı figürünün altındaki fazla çimento temizlenir. yuvadır. Birinci kuşak çimentolama tekniğinde çimento parmakla bastırılarak, kanal hazırlığı yapılmadan dökme sistemiyle, çimento tabancası, meduller tıkaç veya gözenekliliği önleme adına santrifüj kullanılmadan uygulanmaktadır. Ancak uygulama sonrası komponentkemik arası çimento miktarı yetersiz olmaktadır. Bu teknikte 10 yıl sonunda aseptik gevşeme oranları \%30 olarak verilmektedir. ${ }^{[29]}$

İkinci kuşak çimentolama tekniklerinde ise meduller fırça ilemeduller pulsatil yıkama yapılmakta, adrenalin emdirilmiş gazlı bez yerleştirilmektedir.

Üçüncü kuşak çimentolama tekniklerinde ise çimento gözenekliliğini azaltmak için santrifüj sistemi kullanılmaktadır. Bu kuşakta, sap uygulamadan önce çimento ile kaplanmakta (bazı vakalarda çimento ile sap birleşmesini arttırıcı uygulamalar erken gevşemeye neden olabilmektedir), femoral sap için merkezleyici, geriye doğru uygulama ve baskılama için çimento tabancaları kullanılmaktadır.

İkinci ve üçüncü kuşak çimentolama tekniklerinde çimentonun, uygulamadan önce tabanca içerisine 2 dakikada yerleştirilip, toplam 3-4 dakika zarfinda da uygulanması gerekmektedir. Düşük akışkanlık çimentonun tabakalı olarak donmasını engelleyerek polimerize çimentonun zayıflamasını önlediği için, çimentonun daha güçlü olabileceği belirtilmektedir. Çimentonun akışkanlığını azaltmak için, üzerine basınç uygulanmadan önce 4-6 dakika beklenerek sıvı halinden hafif katı hale geçmesi beklenir. Komponent kenarından taşmış olan çimento, kan bulaştığı kabul edilerek çıkarılmalı ve yeni çimento ile boşluklar doldurulmalıdır. Çimento doldurulduktan sonra cihazlarla veya elle bastırılır. ${ }^{[30,31]}$

Birinci kuşak çimentolama tekniklerinin başarısız olması, yeni tasarımlar ve çimentolama tekniklerinin gelişimini teşvik ederken, çimentosuz tespit yöntemleri konusundaki çalışmalara da yol açmıştır. İkinci ve üçüncü kuşak çimentolama teknikleri ve gözenek kaplı çimentosuz implantların kullanılması ile femoral sapın uzun dönem tespitinde başarı sağlanmasına rağmen aseptik gevşeme, osteoliz ve uyluk veya kasık ağrısı gibi sorunlar da devam etmiştir. Son 20 yıldır implantların hidroksiapatit ile kaplanması ile elde edilebilecek sonuçlar üzerine çalışmalar yapılmaktadır. ${ }^{[32]}$

\section{İmplantasyon}

Günümüzde kulanılan komponentler dayanıklılığı çapraz bağlarla geliştirilmiş yüksek dansiteli polietilen (UHMWPE) asetabuler kaplardır. Kap tutucuyla beraber öncelikle inferior yüzeye daha sonra da medial ve superior yüzeye bastırılarak yerleştirilir. Alınan bir parça çimento süperior kenara parmakla yerleştirilerek tutucu ile son pozisyon verilir. Tutucunun çıkarılması ile kap pozisyonu değerlendirilir, aşırı çimento varsa temizlenir. Kap mediale basınç uygulanarak dondurulur.

\section{Komplikasyon ve kontrendikasyonlar}

Radyografik olarak kemik çimento arası ışıngeçirgen alanlar büyük miktarda uygulanan çimentonun yarattığı termal nekroz ya da katılaşma sırasında oluşan \%2'lik büzüşme ile oluşabilmektedir. Derin ven trombozu (DVT) riskini minimuma indirmek için 
ameliyat içi intravenöz heparin infüzyonu uygulanabilir. Böbrek ya da karaciğer transplantasyonu geçiren hastalarda total eklem replasmanı sonrası enfeksiyon oranı \%19 olarak bildirilmektedir. Gerekli durumlarda çimento içerisine antibiyotik eklenebilir. Yetersiz çimentolamadan kaçınmak adına yeni tasarım implantların uygulanmasında, 2 paket $40 \mathrm{~g}$ çimentonun yeterli olup olmadığının kontrol edilmesi gerektiği bildirilmektedir. ${ }^{[33,34]}$

Çimentolu asetabuler komponent uygulaması, belirgin kardiyo-pulmoner hastalığı olan hastalarda (çimento uygulamasından sonra oluşabilecek minimal emboli nedeniyle), oyma sonrası aşırı asetabuler kanaması olan hastalarda, aşırı kist formasyonu ve kansellöz kemik stoğu az olan hastalarda kontrendikedir. Emboli (çimento veya yağ basınçlı çimento uygulaması ardından hipoksi), kardiyak arrest ve ölüm ile sonuçlanabilen bir patolojidir. Bu durum için risk faktörleri; ileri yaş ve patent foramen ovale (paradoksal embolizasyon) olarak bildirilmektedir. Pulsatil yıkama, yağ ve kemik iliği partiküllerini uzaklaştırarak embolizasyon oluşmasını engelleyebilir. Ek hastalıkları fazla olan hastalarda, kanal içerisine basınçlı çimento uygulamalarından kaçınılmalıdır. ${ }^{[35,36]}$

Özellikle belirli endikasyonlar için, çimentolu asetabuler komponentlerin uzun dönemde sonuçları mükemmeldir. Osteoartrit hastalarına yapılan kalça protezlerinin 10-20 yıllık revizyon oranları \%2-14 arasında değişmektedir. Radyolojik olarak aynı dönem içinde gevşeme oranları \%6-23 arasındadır. Literatüre baktığımızda, $32 \mathrm{~mm}$ baş ile uygulanan metal destekli çimentolu kapların romatoid artrit, displazi ve revizyonlar gibi durumlar dışındaki sonuçlarının çok iyi olduğu bildirilmektedir. Kompresyon kalıplı polietilenlerde yıllık aşınma miktarı $0,075 \mathrm{~mm} /$ yıl olarak saptanmıştır. Ritter ve arkadaşlarının ${ }^{[37]}$ yaptıkları çalışmada asetabuler yüzü metal olan ve olmayan kaplar karşılaştırılmıştır. Sonuçlara göre, metal kaplı olanların yıllık lineer aşınma miktarı 0,11 mm/yıl iken metal kaplı ol-

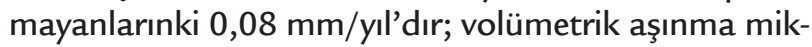
tarı ise, metal kaplı olanlarda $66,2 \mathrm{~mm}^{3} / y ı l$ iken metal kaplı olmayanlarda 48,2 $\mathrm{mm}^{3} / \mathrm{yıl}$ olarak bulunmuştur. Yüksek çapraz bağlı polietilen ve buna alternatif geliştirilen komponentler ortaya çıkana kadar, çimentolu polietilen kapların tüm yaş grupları için "altın standart" olduğu belirtilmektedir. ${ }^{[38]}$ Tamamı polietilen kapların 10-20 yıllık sağ kalım oranı osteoartritik kalçalar için \%99'dur. ${ }^{[39]}$ Aşınma oranı bakımından da metal, üzeri polietilen çimentolu kaplardan daha üstündür (yıllık $0,1 \mathrm{~mm}$ 'den az). On yıldan önce erken yetmezliğin nedeni, ameliyat sırasındaki yetersiz çimento uygulamasıdır. ${ }^{[40]} \mathrm{Bu}$ durum uygulama tekniğine bağlıdır ve erken radyografik görüntülerle belirlenebilir. ${ }^{[32]}$

\section{ÇIMENTOSUZ ASETABULER KOMPONENT}

Çimentolu asetabuler komponentlerin orta-uzun dönem izlemlerinde karşılaşılan kötü sonuçlar nedeniyle geliştirilen çimentosuz implantlar, biyolojik tespit yöntemi olmaları nedeniyle günümüzde giderek artan sıklıkla kullanılmaktadır. Çimentolu asetabuler komponentlere göre artmış konak-implant yüzey uyumu, ameliyat süresini kısaltması, uzun dönem başarılı sonuç elde edilmesi ve biyolojik tespit gelişimi yetersiz olan olgularda kolay revizyon uygulanması, çimentosuz asetabuler komponentlerin avantajlarıdır.

Çimentosuz asetabuler komponentler, değişik tasarımlarda farklı materyallerden üretilmiştir. Morsher, ${ }^{[41]}$ günümüze kadar kullanılan çimentosuz asetabuler komponent şekillerini silindirik (Lindenhof, Judef), konik yivli (Endler, Ring, Zweymüller), elipsoid yivli (Lord), hemisferik (Haris-Galante, Press-Fit) ve kare komponent (Friedrichsfeld) olarak beş tipe ayırmıştır.

Çimentosuz asetabuler komponentlerin biyolojik tepitinin güçlendirilmesi için geliştirilen gözenekli yüzey kaplı implantlar, hemisferik şeklinden dolayı kolay yerleştirilmesi, modüler polietilen ara parçalar sayesinde eklem yüzeyinin değiştirilmesine olanak sağlaması gibi avantajları nedeniyle sık tercih edilen implantlardır. ilk kullanılan gözenekli yüzey kaplı asetabuler komponentler, krom kobalt alaşımlı ve rotasyonel stabilite sağlanması için iki adet periferik çıkıntısı (peg) olan ve titanyum alaşımlı vida ile tespit edilen implantlardı. Günümüzde ise hemisferik veya modifiye hemisferik şeklinde olan gözenekli yüzey kaplı komponentler, krom-kobalt, saf titanyum, titanyum temel alaşımlı olup yüzey kaplaması olarak ise krom-kobalt yuvarlak küçük parçacıklar (sintered cobalt-chromium beads), titanyum yuvarlak küçük parçacıklar, kansellöz yapılı titanyum, titanyum fiberli partiküller (plasma sprayed) kullanılmaktadır. Bir başka yöntemse, kendinden poroz metallerden imal edilmiş komponentlerin kullanımıdır. Gözenekliliği \%80 olan tantalum buna iyi bir örnektir. ${ }^{[22]}$ Yüksek sürtünme özelliği sayesinde erken dönemde istenen stabilite elde edilmekte, uzun dönemde ise gözenekli titanyum alaşımın osteoindüktif etkisi sayesinde yeterli kemik gelişimi sağlanmaktadır. Arka yüzde destekleyici sert metale ihtiyaç duyulmaması da arka yüzey aşınmasını ortadan kaldırmaktadır. Tantalum maddesinin elastik modulusunun kemiğe daha yakın olması da stres kalkanı oluşumunu azaltmaktadır. Meneghini ve ark. ${ }^{[43]}$ monoblok çimentosuz asetabuler komponentlerin 7,5 yıllık takibi sonucunda, titanyum asetabuler komponentler etrafinda kemik yoğunluğunda azalma olurken, tantalum komponent etrafında yoğunluk artışı olduğunu bildirmişlerdir. 
Gözenekle kaplanmış yüzeylerde, metal yüzeyde oluşturulan gözenekler kemiğin içeri doğru büyümesine izin verir. Gözenekliliğin fazla arttırıması zararlıdır çünkü gözenek kaplı yüzey makaslama riski altında olabilir. Protez ile kemik arasındaki boşluk 50 mikrometreden daha az tutulmalıdır.

Gençlerde, genelde aktif ve hareketli oldukları için, kalça eklemine yaşlı hastalara oranla daha fazla yük binmektedir. Bundan dolayı, çimentolu total kalça replasmanında daha fazla gevşeme oranları saptanmıştır. Çimentolu protezlerdeki gevşemenin nedeni tekrarlayan yüklenmeler sonrası oluşan mikrokırıklardır. Çimentosuz biyolojik tespit sonrası tekrarlayan mikrokırıklar gelişmesine rağmen, kemiğin kendini yenileme ve iyileştirme potansiyeli mevcuttur.

Gevşemenin en az olması için başarılı bir rijit tespit gereklidir. Protezin mikro hareketi 150 mikrometre altında tutulmalıdır, aksi takdirde protez sadece fibröz doku ile sarılır. Bu nedenle, çimentosuz komponentlerin yerleştirilme tekniği çok önemlidir. Temel rijit tespit genellikle 'basınçlı yerleştirme' tekniği ile sağlanabilir. Burada kemik komponentlerden hafif küçük olacak şekilde hazırlanır (genellikle 1-2 mm küçük). Çember stresi protezi korur. Diğer teknik ise ucu-ucuna tekniğidir. İlave tespit için vida gereklidir. İçe büyüme için diğer bir önemli nokta ise, implantın kansellöz kemik yerine kortikal kemik üzerine oturtulmasıdır. Bu nedenle asetabulumda asetabuler kap ile kortikal kenar arasında uyumun sağlanması önemlidir.

Ideal olarak; kayma ve rotasyon hareketlerinin olduğu eklemleşen yüzeylerde kullanılan materyalin kuvvete ve aşınmaya karşı yüksek dirence sahip olması istenir.
Bütün bu özelliklere sahip tek bir materyal yoktur. Çimentosuz asetabuler komponentler seramik, $\mathrm{Cr}-\mathrm{Cr}$ Mo, Ti-Al-Vitalium, Co-Cr ya da Ti gibi farklı alaşımlardan yapılmıştır. Günümüzde çimentosuz asetabuler komponent ile kemik arasındaki osteointegrasyonun güçlendirilmesi amacıla farklı alaşımlardan yapılan yüzeyi gözenekli implantlar, hidroksiapatit kaplama eklenerek de kullanılmaktadır. HA (hidroksiapatit) osteokondüktif bir ajandır. Kemik ile kap arasındaki boşluğu kapatmaktadır. En sık uygulanan tasarım metal femoral baş ile polimerize asetabuler kaptan oluşan tasarımlardır. Bu protezlerde karşılaşılan en önemli komplikasyon, polimer kapın aşınmasına bağlı gelişen enflamatuar reaksiyon ile oluşan aseptik gevşemedir (Şekil 5). Bu durum ameliyattan yıllar sonra oluşur ve revizyon cerrahisi ihitiyacını artırır. Aseptik gevşeme metal-metal veya seramik-seramik protezlerde daha az görülür. Metal-metal protezlerde metal iyon salınımına bağlı başlıca kontrendikasyonlar, şiddetli metal alerjisi olan, renal yetmezliği olan ve doğurganlık yaşındaki hastalardır.

\section{Cerrahi teknik}

Cerrahi yumuşak doku çıkarılarak asetabuluma ulaştıktan sonra labrum asetabulumdan ayrılır. Yumuşak dokular temizlenerek inferomedialde osteofitler varsa osteotom ile çıkarılarak kotiloid fossanın tabanı ortaya konur. Ameliyat öncesi radyografik değerlendirmeler ve rehber görsellere dayanarak, ölçülen asetabulum boyutundan yaklaşık 6-10 mm daha küçük boyutta oyucu ile asetabulum oyulmaya başlanır. Bu aşamada en önemli nokta kotiloid fossanın medialinin daha

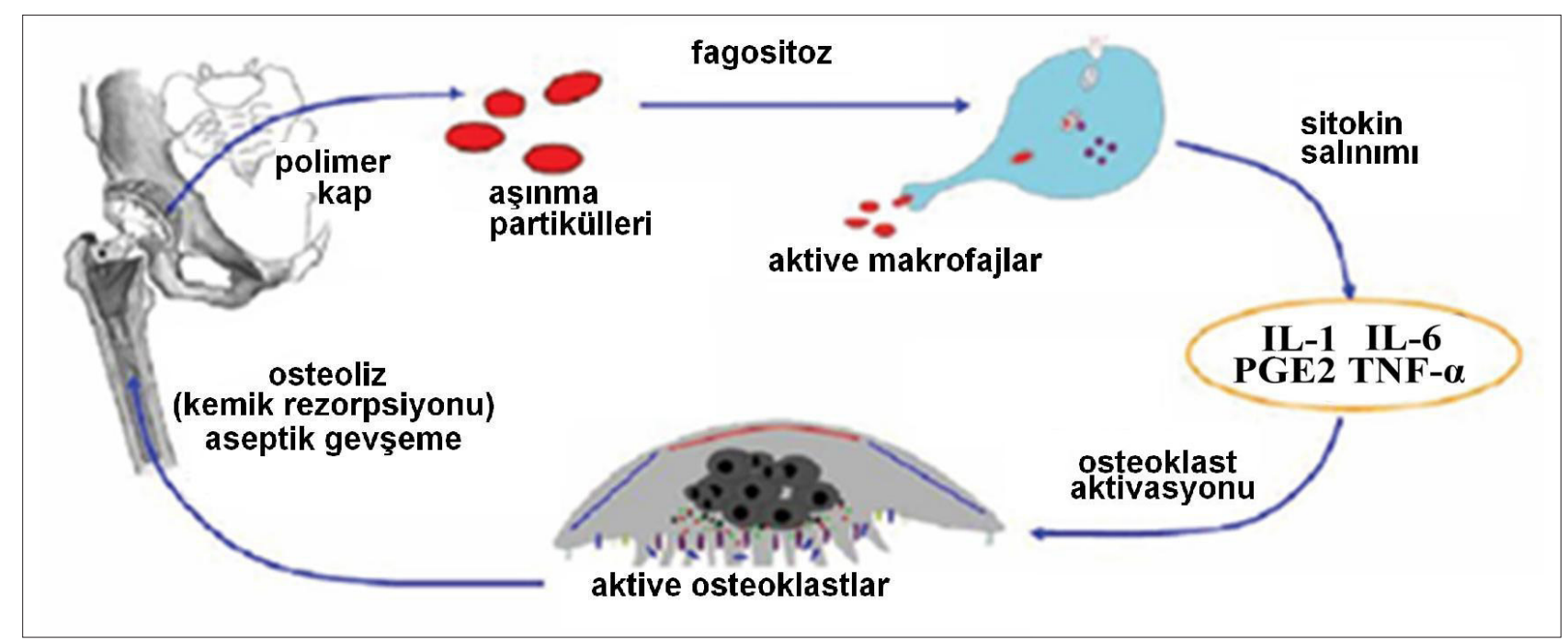

Şekil 5. Aseptik gevşeme. 
küçük boyuttaki oyucu ile oyulmasıdır. Cerrah bu sırada, hasta lateral pozisyondayken, neredeyse zemin ile dik açı oluşturacak şekilde oyucuyu elle kullanır ve fossanın en lateral kenarının ön ve arka kısımlarını çıkararak kotiloid fossayı tamamen ortaya koyar. Daha sonra oyucu asetabuler kapın yerleştirileceği pozisyona getirilerek oymaya devam edilir. Bu pozisyon $35-40^{\circ}$ abduksiyon ve $15-30^{\circ}$ anteversiyon/fleksiyon konumunda olmalıdır. Doğrudan lateral ya da anterolateral yaklaşım uygulanıyorsa, anteversiyon $15-20^{\circ}$, posterolateral yaklaşımda ise $20-25^{\circ}$ olmalıdır. Sonraki aşamada asetabulum 1-2 mm artışlarla oyularak genişletilir. Asetabuler oyucu; asetabulumun ön ve arka duvarlarına iyi bir şekilde yerleştirildikten sonra, dikkatlice oyma yapılır. Bu noktada cerrah, gözenekli yüzeye doğru iyi kemik büyümesi gerçekleşebilecek yeterli kansellöz ve subkondral kemiğin açığa çıkarıldığına emin olmalıdır. Eğer iyi kanlanmayan sklerotik kemik ve kıkırdak dokusu mevcutsa cerrah daha fazla oyma yapmalı, asetabulum boyutunu büyütmeli, fakat yeterli anteroposterior kemik stoğunun kaldığını da kontrol etmelidir. Sıkı asetabuler oyma yapıldıktan ve iyi kanama yüzeyleri elde edildikten sonra cerrah pelvisi oyucu ile beraber öne ve arkaya sallar, asetabulum ve oyucu arasında minimal bir hareket görülür. Eğer bu noktada 'sferite'den şüphe duyuluyorsa kubbe ve kenar temas uyumunu anlamak için deneme komponenti uygulanabilir. Son oymadan 1 veya $2 \mathrm{~mm}$ daha büyük asetabuler komponent, kap sokma cihazına konulur ve son implant hazırlanan asetabuluma yerleştirilir. Olası asetabuler kırık nedeniyle aşırı ezme kuvvetinden kaçınılır. Ezme sırasında asetabuler komponentin pozisyonunun değişmemesine dikkat edilir. Komponent yerleştirildikten sonra el ile denenir. Eğer anteroposterior ya da superoinferior yönlerde hareket saptanırsa, asetabulumun posterosuperior kadranına destek vidaları yerleştirilir. Hiç hareket yoksa yıkama yapılır. Eğer modüler komponent kullanıldıysa, yük taşıyan yüzey ara parça yerleştirilerek kilitlenir.

Çimentosuz asetabuler komponentlerin başlangıç tespiti komponentin çeperine bağlı anti-rotasyon çıkıntılar (peg), çeperindeki sivri çıkıntılar (spike), kansellöz vidalar ve 'basınçlı yerleştirme' olarak dört şekilde temin edilebilir. Çimentosuz asetabuler komponentin vida tespiti ile uygunsuz oyma sonrası boşluklar kapatılabilir ve asetabuler komponentte kompresif kuvvet kaybı önlenebilir. Kemik kalitesi kötü olduğunda, vida ile ek stabilite sağlanır. Vida ile tespit için güvenli bölgeler Wasielewski tarafından tarif edilmiştir. ${ }^{[4]}$ Buna göre posterosuperior alanda $35 \mathrm{~mm}$ 'nin altındaki, posteroinferiorda ise $25 \mathrm{~mm}$ 'nin altındaki vidalar tespit için uygun kabul edilmektedir (Şekil 6). Bununla birlikte ameliyat süresinin uzaması, yeterli başlangıç stabilitesi olduğunda biyolojik tespit üzerinde etkisinin olmaması, venöz, arteryel ve nöral yapıların uygulama sırasında etkilenme ihtimalinin olması, vida ile tespitin dezavantajlarıdır. Ayrıca vida delikleri aşınma ürünleri için bir yol teşkil edebilir ve kemik implant yüzeyinde gevşemeye yol açar. Delik sayısı revizyon ameliyatları dışında 2-3'ten fazla olmamalıdır. Böylece kemikle entegre olacak alan en fazla olur. Vida deliklere eksenden kaçık olarak yerleştirilirse, polietilen asetabuler komponent içerisinde stabil olarak durmaz. Ayrıca eksenden kaçık yerleşimli bu vidalar kaldıraç gibi davranarak asetabuler komponenti zamanla kemik yatağından kaldırabilir. Çimentosuz asetabuler komponentin öncelikli tespitinde bir başka yöntem olan 'basınçlı yerleştirme' uygulamasında en son oyulan kısmın boyutundan 1-2 mm daha büyük asetabuler komponent yerleştirilir. Amaç, vida veya çıkıntı ihtiyacı olmadan 'düğme kilitleyici' mekanizmayla tespiti sağlamaktır. Bu mekanizma ile asetabulumun kubbesi yük altında düzleşir ve kubbede temassız yüzey oluşurken periferde asetabuler komponent asetabulum kenarları tarafindan sıkıştırılır. Böylece yüksek basınç kubbe yerine çeperlere iletilir (Zone 1-3). Osteointegrasyon başlangıçta Zone 2'de az olsa bile 2 yıl sonunda yeterli hale gelir. Oyma işleminin kalitesine ve çapına çok dikkat etmek gerekir. Zira Huo ve ark. ${ }^{[45]}$ oyma çapındaki 0,75 mm'lik bir artışın 'basınçlı yerleştirme' komponentlerinin tespit gücünde $\% 56^{\prime}$ ।ık bir azalmaya yol açtığını göstermişlerdir.

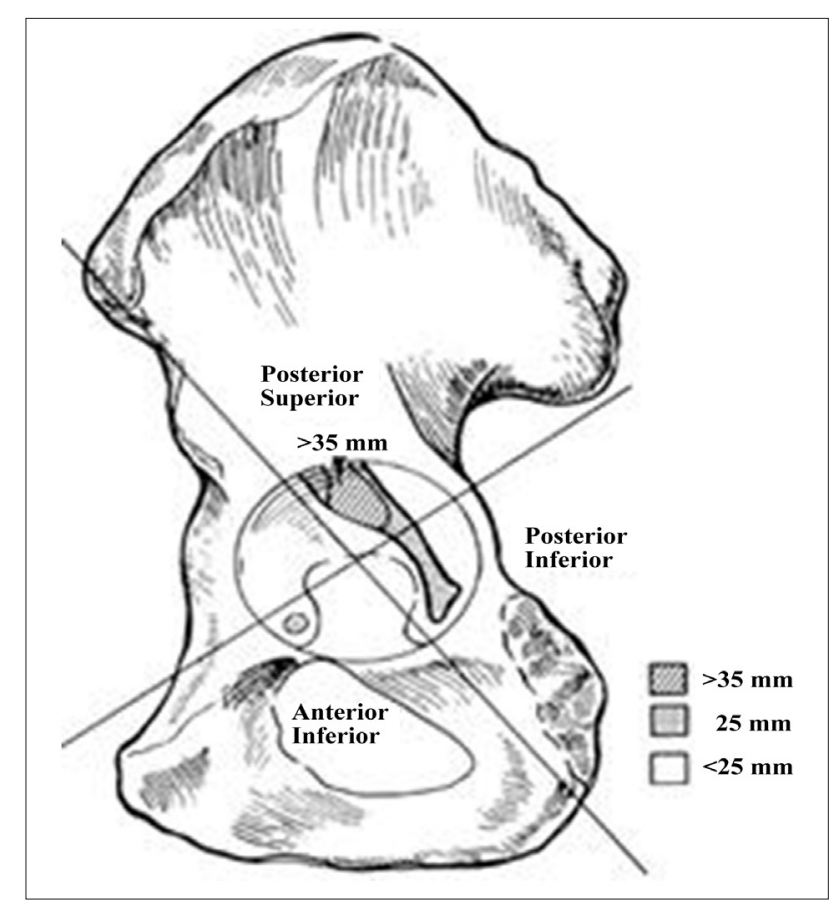

Şekil 6. Vida tespiti için güvenli alanlar. 


\section{ÇIMENTOLU - ÇIMENTOSUZ ASETABULER KOMPONENTLERIN KARŞILAŞTIRMASI}

Çimentolu TKP uygulamalarının orta dönem izlemlerinde, özellikle asetabuler komponentte aseptik gevşeme, kemiğin lokal lizisi ve gevşemenin hızlanması "çimento hastalığı" gelişmesine bağlanmış, alternatif tespit yöntemlerinin araştırılmasına neden olmuştur. ${ }^{[46]}$ Konak kemiği koruyan ve biyolojik tespite olanak sağlayan çimentosuz implantlar ile özellikle aktif, genç yaştaki olgularda aseptik gevşeme oranı azaltılabilmiş ve başarılı TKP sonuçları elde edilmiştir. Fakat bu implantlarla da gevşeme ve lokal lizis meydana gelmiş ve sorunun çimentodan değil, kemikte oluşan fizyolojik olmayan yük dağılımından kaynaklandığı ortaya çıkmıştır. Daha önce "çimento hastalığı" olarak adlandırılan bu durum bugün stres kalkanı olarak tanımlanmaktadır. Amerikan ulusal eklem replasman kayıtlarına göre asetabuler kaplar femoral saplara göre yüksek yetmezlik oranları ve revizyon ameliyatı oranına sahiptir. ${ }^{[38]}$ Asetabuler kap yetmezlik mekanizmaları; aseptik gevşeme, çıkık, polietilen aşınması ve osteolizdir. ${ }^{[47,48]}$ Literatürde, çimentolu ve çimentosuz kapların sağ kalım oranlarına dair yapılan çalışmalarda, aseptik gevşeme açısından çimentosuz kapların daha iyi olduğu belirtilmektedir. Ancak, çimentosuz kapların osteointegrasyonu arttıran tasarımlarının geliştirilmesi, çimentolu kaplar için de çimento uygulama tekniklerinin gelişmesi her iki kap için radyolojik olarak gevşeme göstergelerinin azalmasına ve erken migrasyonun azalmasına yol açmıştır. ${ }^{[49-52]}$

Aşınma miktarına göre incelendiğinde yapılan çalışmalar, her iki kap çeşidi için sonuçların eşit ya da çimentosuz kaplar için bir miktar fazla aşınma oranı olduğunu göstermektedir. Çimentosuz kaplarda aşınma oranı ve osteoliz erken dönemde hızlı ve aşırıdır. 12-16 yıl sonunda sağ kalım oranı \%50-70 oranında düşmektedir. ${ }^{[53]}$ Benzer bulgular, Morshed ve arkadaşlarının ${ }^{[54]}$ yaptığı çalışmada da ortaya konmuş ve çimentolu kaplardaki aşınmanın ve osteolizin daha az olmasını da çimentonun şok emilim özelliğine bağlı olabileceği belirtilmiştir. Bjerkholt ve arkadaşlarının ${ }^{[55]}$ yaptığı bir çalışmada çimentolu ve çimentosuz kaplar karşılaştırılmıştır. Genç hastalarda ve artmış inklinasyon açılarında tespit yönteminden bağımsız olarak, aşınmanın daha fazla olduğu belirtilmiştir. Aşınma miktarındaki artış aktivite düzeyindeki artış ile ilişkili bulunmuştur. [55,57] Bu bilgiler ışı̆̆ında doğru yönelim uygulanması ile çimentosuz kapların aşınma oranının çimentolu kaplardan daha fazla olmaması sağlanabilir. Chawda ve ark. ${ }^{[58]}$ yaptıkları navigasyonlu yönelim çalışmalarında, çimentosuz kapların yerleştirilmesinin daha zor olduğunu belirtilmişlerdir.
Çıkık açısından değerlendirildiğinde çimentosuz kaplarda çıkık oranının çimentolu kaplara göre daha fazla olduğu saptanmıştır. Ameliyat sırasında çimentosuz kapların manipülasyonunun daha zor olması ve bu yüzden Lewinnek'in güvenli sahasında tespitin yapılamaması bunun nedeni olarak gösterilmektedir. ${ }^{[59]}$ Chawda ve ark. ${ }^{[58]}$ yaptıkları navigasyon çalışmalarında çimentosuz kapların yerleştirilmesinde inklinasyon açılarında \%20, abduksiyon açılarında \%35 oranında $5^{\circ}$ veya daha fazla sapma olduğunu göstermişlerdir.

Çimentolu ve çimentosuz kapların sağkalımı açısından İsveç Kalça Artroplasti Grubu tarafindan yapılan çalışmada, cinsiyet, yaş ve teşhis gibi faktörlerin homojen dağılımı sağlandığında çimentosuz kapların, aseptik gevşeme nedeniyle, çimentolu kaplardan 1,8 kat daha fazla revizyona gerektirdiğini belirtilmektedir. ${ }^{[60]}$ Literatürde, bu gibi sonuçları olan çalışmaların ortak kararı, çimentosuz protezlerin genç yaş grubuna uygulanması gerektiği yönündedir. ${ }^{[61,62]}$

\section{TOTAL KALÇA ARTROPLASTISINDE YÜZEY SEÇENEKLERi}

Polietilenin aşınma hızı asetabuler implant tasarımına, femur başı materyaline, polietilen tipine ve sterilizasyon yöntemine bağlıdır. Asetabuler komponent ile ara parça arasındaki uyum ve kilitlenme mekanizması yeterli olmalıdır. Komponent ile ara parça arasındaki bağlantının yeterli olmaması sonucu meydana gelen mikro hareketler PE'de hasara yol açarak debris oluşumunu hızlandırır. Polietilen kalınlığının en az 6-8 mm olması, $28 \mathrm{~mm}$ veya daha ufak femur başı kullanılması, çapraz bağlı polietilen kullanılması, PE aşınmasını yavaşlatacaktır. ${ }^{[63]}$ Ayrıca komponentin uygunsuz yerleştirildiği durumlarda açılı ara parçaların kullanılmasının çok az ek stabilite sağladığı ancak osteolizisi arttırdığı bildirilmiştir. ${ }^{[64]}$ Hareket açıklığı bazı yönlerde artarken bazı yönlerde azalır. Deformasyon ve geç çıkık sık görülen komplikasyonlardır. PE partiküllerden başka sap veya asetabuler komponentten kaynaklanan metal partikül debrisi de aşınmada rol oynar.

Yeni kuşak asetabuler komponentlere örnek olarak "at nalı" tasarımlar verilebilir (Şekil 7). Asetabulum eklem yüzeyinin anatomik yapısını taklit eden bu modellerde at nalı şeklinde, distal kısmı açık komponentler kullanılır. Fizyolojik yük dağııımına benzer mekaniğe sahip bu tasarımlar ile asetabulum çatısında artmış yüklenme olur ve kemik kaybı azalır. ilk geliştirilen model olan "Cambridge Cup"ta kemik entegrasyonu hidroksiapatit kaplamalı yüzey ve birkaç adet ufak çıkıntı ile elde edilmiştir. Eklem yüzeyi polietilenden oluşturulmuş, yük taşıyan kabuk ise karbon-fiber ve poli-bütilen-eter-fitalat kompozitten imal edilmiştir. 

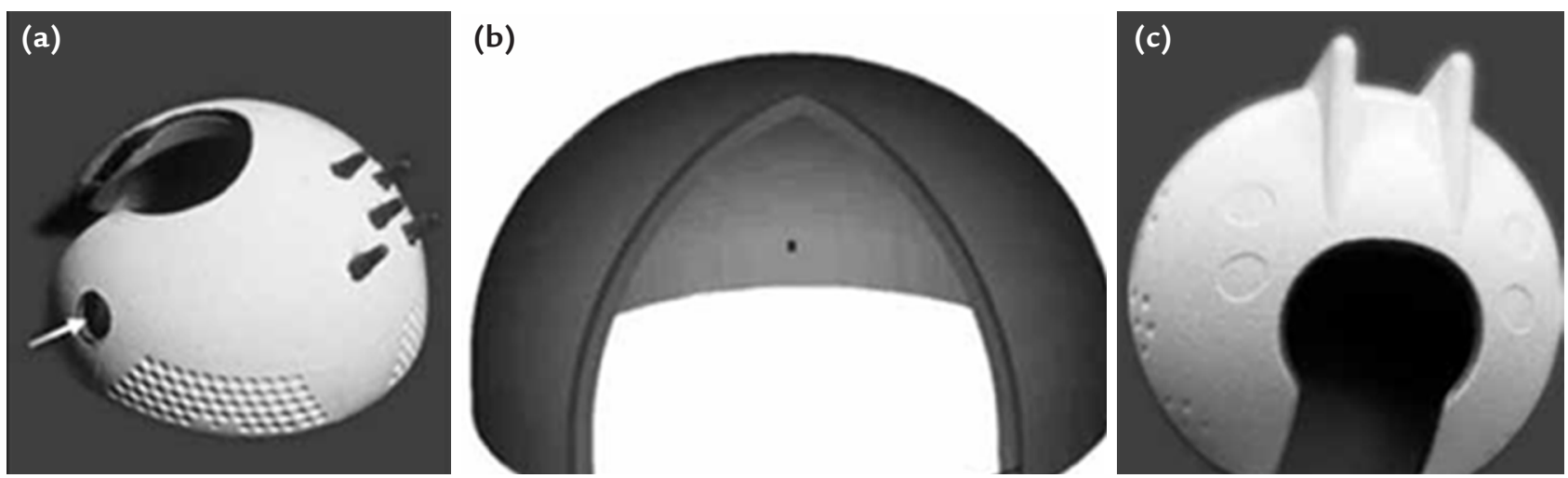

Şekil 7. Dışı hidroksiapatit kaplı ve ufak çıkıntılarla desteklenmiş “Cambridge Cup” (a). Cambridge Cup'ın katmanları (b). MITCH PCRTM Cup (c). UHMWPE: Çok yüksek moleküler ağırlıklı polietilen.

$\mathrm{Bu}$ modelin geliştirilmesiyle elde edilen "MITCH PCR Cup" tasarımında ise polietilen yüzey kaldııımış, eklem yüzeyi ve kabuk tek parça karbon-fiber ve polieter-eter-keton kompozitten yapılmıştır. Dış yüzeydeki HA kaplama korunurken ufak çıkıntılar yerine daha büyük iki kanat eklenmiştir. ${ }^{[65]}$

Kalça replasman cerrahisinde geleneksel uygulama yumuşak üzerine sert birleşimi şeklindedir. Metal bir baş ve ona uyan polietilen kabı içermektedir. Bir diğer ikili ise seramik başa uyan PE kaptır. Metalik baş seçeneğinde Co-Cr-PE birleşimi en iyi birleşim olarak düşünülmektedir. Ti alaşımlı başlar tercih edilmemelidir. Pürüzlü hasarlanmış bir yüzey PE yüzeyinin çabuk aşınmasına neden olacaktır. Metal-PE ve seramik-PE birleşimlerinde aşınma, baş yüzeyinin pürüzlülüğü ve yuvarlaklı̆g ile ilgilidir.

Yumuşak üzerine sert ürünlerde yağlanma şekli her zaman 'boundary' yağlanma şeklindedir. Burada yağlayıcı (örn. sinoviyal sıvı) karşııılı iki yüzey pürüzlerinin temasını önleyecek kadar kalın değildir, fakat aşırı aşınmada koruyacak kadar iki yüzeyi birbirinden ayırır.

Tüm yumuşak üzerine sert malzeme birleşimlerinde osteolize ve yetmezliğe yol açan majör faktör PE aşınmasıdır. PE hasarı, PE üretimine, işlem sonrası sterilizasyon yöntemine ve depolanma süresi gibi faktörlere bağlıdır. Polietilen olarak ultra-yüksek molekül ağırlıklı polietilen (UHMWPE) kullanılmaktadır. UHMWPE'ler 4 farklı teknikle üretilmektedir:

1) Ram çubuklarından ikinci bir işlemle üretim,

2) Büyük plaklara sıcak izostatik presleme işlemi ile istenen ürünün çıkartılması,

3) Çubukların kompresyonla şekillendirilmesi işlemi ile istenen ürünün çıkartılması ve

4) Direkt kompresyon şekillendirme ile PE tozunun istenen ürüne dönüştürülmesi.
Dördüncü teknik ile daha az aşınma oranları tespit edilmiştir. Üretilen PE'nin sterilizasyonu radyasyonlu ve radyasyonsuz olmaktadır. Düşük doz radyasyonlu sterilizasyon sonrası PE'nin çapraz bağlanma eğilimi artmakta, bu da aşınma miktarını azaltmaktadır. Üretilen implanttaki PE iki farklı fazda karşımıza çıkmaktadır: kristalin faz ve amorf faz. PE'nin \%70'ten fazla kristalleştirilmesi yüksek PE başarısızlığı demektir. Yüksek doz radyasyon tekniği kullanılırken üretim tekniği kristal fazını \%50-56'da tutmalıdır. Yüksek doz radyasyon genellikle ikincil yöntem olarak kalan serbest radikallerin uzaklaştırılması için yapılan ısıtmayı içerir. Yüksek ısıtmada ise eğer kaynama noktası geçilirse kristalize miktar artar, bu da dayanıklılığı azaltmaktadır. Çapraz bağlanmalar artarsa mekanik özellikler azalır. Radyasyon uygulama şekli ve paketleme şekli, rafta beklerken, PE performansını etkilemektedir.

Sert üzerine sert yüzey uygulamaları, PE yıpranması sonucu osteoliz oluşmasından dolayı alternatif olarak düşünülmektedir. Sert üzerine sert uygulamalarda çok daha küçük debrisler oluştuğundan osteolitik reaksiyon miktarının daha az olduğu düşünülmektedir. Metal-metal ürünlerde, kan ve idrarda kobalt ve krom düzeylerinin arttığı ortaya konmuştur. Şimdiye kadar uzun dönemde neoplazi ile primer bir ilişki bulunamamıştır. Metal-polietilen ve metal-metal uygulanan protezler etrafindaki yumuşak doku incelemeleri karşılaştırıldığında, Campell ve ark. ${ }^{[66]}$ metalmetal protezlerde daha fazla lenfosit saptamışlardır. Bir diğer çalışmada Willert ve ark. ${ }^{[66]}$ yetmezliğe uğrayan metal-metal protezlerin etrafinda perivasküler lenfosit birikimi saptamışlardır. Metal aşınmasının ürünlerine karşı gelişen immünolojik reaksiyon sonucu oluşan perivasküler lenfosit birikimi komponent yetmezliğini açıklasa da, yazar bu patolojiye ek olarak Tip 4 geç hipersensitivitenin komponenti 
olmayan plasma hücreleri, B lenfositler ve aşırı fibrin eksudanın varlığını bildirmişlerdir. Bu durumu ALVAL (aseptic lymphocyte-dominated vasculitis-associated lesion) veya LYDIA (lymphocyte-dominated immunologic answer) olarak tanımlamıştır. ${ }^{[67]}$ Sert-sert ürün birleşimlerinde başarı birçok faktöre bağlıdır; yüzey pürüzlülüğü, yuvarlaklık, radial aralıktır. Radyal aralık kap ve başın yarıçap farkı olarak tanımlanmaktadır. Başın yarıçapı kaptan daha büyük ise yüzey teması ekvatoryeldir. Böylece yüksek sürtünme kuvveti oluşur. Baş kaptan küçük olursa ürün teması polardır ve yine yüksek sürtünme ve aşınma gerçekleşmektedir. Optimum tasarım yüksek ürün uyumlu polar temastır. Bu durumda radyal aralık küçüktür. Düşük radyal aralık, temas yüzeyinde yağlamanın içeri ve dışarı doğru olabilmesi için yeterlidir.

Optimum yağlama için sert yüzeyler oldukça pürüzsüz olmalıdır. Sferik yüzeydeki fiziksel farklılıklar küçük yüksek noktalar oluşturur. Bu yağlamayı etkileyen ve aşınmayı arttıran lokalize stres noktalarına neden olur. 'Run in' periyodunda yani ilk bir milyon siklusta aşınma yüksek orandadır; daha sonrasında yüzey kabarıklıkları taşıma yüzeyiyle aynı seviyeye gelerek ve aşınma oranları azalarak sabit hale gelir.

\section{SONUÇ}

TKP uygulamaları birincil veya ikincil olarak gelişebilen koksartrozlardaki eklem ağrılarını azaltmaya, yaşam kalitesini yükseltmeye ve fonksiyonel bir kalça eklemi elde etmeye yönelik ameliyatlardır. Kalça protezlerinin ömrünü uzatmak, komplikasyon ve revizyon ameliyatlarını azaltmak üzere araştırmalar devam etmektedir. Bu çalışmalar ışı̆̆ında kalça için birçok protez tasarımı mevcuttur ve hızla yeni tasarımlar geliştirilmektedir. Klinik olarak kalça protezlerinin uzun dönem sonuçları, protez tasarımlarına, hastaların sağlık düzeyine ve ameliyat sonrası aktivite düzeylerine bağlıdır. Ayrıca, cerrahın kalça protezi konusundaki bilgi ve becerisi de önemli bir unsurdur.

Günümüzde kalça protezi uygulamalarında, endikasyonu hastanın yaşı, aktivite düzeyi, altta yatan patoloji ve cerrahın deneyimi belirlemektedir. ${ }^{[68,69]}$ Çimentolu kaplar genellikle 65 yaş üzeri 'basınçlı yerleştirme' ile tespit için yeterli kemik desteği olmayan hastalar için önerilirken, çimentosuz protezler daha genç hastalarda iyi bir kemik kalitesi olan aktif hastalarda tercih edilmektedir. ${ }^{[69]}$ Uygun endikasyon ve uygun cerrahi teknik uygulandığı takdirde, çimentolu ve çimentosuz protezlerin sağ kalım süreleri, aseptik gevşeme oranları, revizyon ihtiyaçları ve fonksiyonel bir kalça elde etme adına birbirlerine net bir üstünlükleri yoktur.

\section{KAYNAKLAR}

1. Callaghan JJ, Rosenberg AG, Rubash HE, editors. The Adult Hip. 2nd ed. New York: Lippincott Williams \& Wilkins; 2007. p. 852.

2. Kurtz S, Ong K, Lau E, Mowat F, Halpern M. Projections of primary and revision hip and knee arthroplasty in the United States from 2005 to 2030. J Bone Joint Surg Am 2007;89(4):780-5.

3. Harkess JW. Kalça Artroplastisi, Campbell's Operative Orthopaedics. 10. baskı. İstanbul: Mosby ve Hayat Tıp Kitapçılık; 2007. s. 315-482.

4. Lambugnani L. La decapitazione del femore nella lussazione congenita dell'anca. Giorn R Acad Med Torino 1885;33:538-551.

5. Smith-Petersen MN. The classic: Evolution of mould arthroplasty of the hip joint. Clin Orthop Relat Res 1978;(134):5-11.

6. Smith-Petersen MN. Evolution of mould arthroplasty of the hip joint. 1948. Clin Orthop Relat Res 2006;453:17-21.

7. Venable CS, Stuck WG. Clinical uses of vitallium. Ann Surg 1943;117(5):772-82.

8. Eftekhar NS. Total Hip Arthroplasty. Volume 1, Chapter 1. St. Louis, Missouri: Mosby-Year Book; 1993. p. 3-14.

9. Moore AT, Bohlman HR. Metal hip joint: a case report. 1942. Clin Orthop Relat Res 2006;453:22-4.

10. Moore AT, Bohlman HR. The classic. Metal hip joint. A case report. Clin Orthop Relat Res 1983;(176):3-6.

11. Ege R. Kalça ile ilgili tarihi gelişme. Kalça cerrahisi ve sorunları. Ankara: THK Matbaası; 1994. s. 51-69.

12. Kaya F. Çimentosuz Total Kalça Artroplastisi Orta Dönem Sonuçları, Uzmanlık Tezi, Ondokuz Mayıs Üniversitesi Tıp Fakültesi, Ortopedi ve Travmatoloji Anabilim Dalı, Samsun, 2005.

13. Charnley J. Anchorage of the femoral head prosthesis to the shaft of the femur. J Bone Joint Surg Br 1960;42-B:28-30.

14. Charnley J. The long-term results of low-friction arthroplasty of the hip performed as a primary intervention. J Bone Joint Surg $\mathrm{Br}$ 1972;54(1):61-76.

15. Dupont JA, Charnley J. Low-friction arthroplasty of the hip for the failures of previous operations. J Bone Joint Surg $\mathrm{Br}$ 1972;54(1):77-87.

16. Dumbleton J, Manley MT. Hydroxyapatite-coated prostheses in total hip and knee arthroplasty. J Bone Joint Surg Am 2004;86-A(11):2526-40.

17. Capello WN, D’Antonio JA, Manley MT, Feinberg JR. Hydroxyapatite in total hip arthroplasty. Clinical results and critical issues. Clin Orthop Relat Res 1998;(355):200-11.

18. Savory CG, Hamilton WG, Engh CA, Valle CJD, Rosenberg AG, Galante JO. Hip Designs. Orthopaedic Knowledge Update: Hip and Knee Reconstruction. Barrack RL, Booth RE, Lonner JH, editors. 3rd ed. Rosemont, Illionis: American Academy of Orthopaedic Surgeons; 2006. p. 345-368.

19. Callaghan JJ, Salvati EA, Pellicci PM, Wilson PD Jr, Ranawat CS. Results of revision for mechanical failure after cemented total hip replacement, 1979 to 1982 . A two to five-year follow-up. J Bone Joint Surg Am 1985;67(7):1074-85.

20. Charnley J. Low Friction Arthroplasty of the Hip. In Theory and Practice. Berlin: Springer Verlag, Berlin-Heidelberg-New York; 1981.

21. Schulte KR, Callaghan JJ, Kelley SS, Johnston RC. The outcome of Charnley total hip arthroplasty with cement after a minimum twenty-year follow-up. The results of one surgeon. J Bone Joint Surg Am 1993;75(7):961-75. 
22. Cates HE, Faris PM, Keating EM, Ritter MA. Polyethylene wear in cemented metal-backed acetabular cups. J Bone Joint Surg Br 1993;75(2):249-53.

23. Ranawat CS, Rawlins BA, Harju VT. Effect of modern cement technique on acetabular fixation total hip arthroplasty. A retrospective study in matched pairs. Orthop Clin North Am 1988;19(3):599-603.

24. Mulroy RD Jr, Harris WH. The effect of improved cementing techniques on component loosening in total hip replacement. An 11-year radiographic review. J Bone Joint Surg $\mathrm{Br}$ 1990;72(5):757-60.

25. Li S, Burstein AH. Ultra-high molecular weight polyethylene. The material and its use in total joint implants. J Bone Joint Surg Am 1994;76(7):1080-90.

26. Muratoglu OK, Bragdon CR, O'Connor DO, Jasty M, Harris $\mathrm{WH}$. A novel method of cross-linking ultra-highmolecularweight polyethylene to improve wear, reduce oxidation, and retain mechanical properties. Recipient of the 1999 HAP Paul Award. J Arthroplasty 2001;16(2):149-60.

27. Kavanagh BF, Dewitz MA, Ilstrup DM, Stauffer RN, Coventry MB. Charnley total hip arthroplasty with cement. Fifteen-year results. J Bone Joint Surg Am 1989;71(10):1496-503.

28. Ritter MA, Keating EM, Faris PM, Brugo G. Metal-backed acetabular cups in total hip arthroplasty. J Bone Joint Surg Am 1990;72(5):672-7.

29. Stauffer RN. Ten-year follow-up study of total hip replacement. J Bone Joint Surg Am 1982;64(7):983-90.

30. McCaskie AW, Barnes MR, Lin E, Harper WM, Gregg PJ. Cement pressurisation during hip replacement. J Bone Joint Surg Br 1997;79(3):379-84.

31. Weber BG. Pressurized cement fixation in total hip arthroplasty. Clin Orthop Relat Res 1988;(232):87-95.

32. Ranawat CS, Deshmukh RG, Peters LE, Umlas ME. Prediction of the long-term durability of all-polyethylene cemented sockets. Clin Orthop Relat Res 1995;(317):89-105.

33. Davies JP, Jasty M, O'Connor DO, Burke DW, Harrigan TP, Harris WH. The effect of centrifuging bone cement. J Bone Joint Surg Br 1989;71(1):39-42.

34. Wixson RL. Do we need to vacuum mix or centrifuge cement? Clin Orthop Relat Res 1992;(285):84-90.

35. McClelland D, Bracy D. Cement venogram--a risk of satisfactory cement pressurization. J Arthroplasty 2006;21(1):141-3.

36. Stauffer RN. Ten-year follow-up study of total hip replacement. J Bone Joint Surg Am 1982;64(7):983-90.

37. Cates HE, Faris PM, Keating EM, Ritter MA. Polyethylene wear in cemented metal-backed acetabular cups. J Bone Joint Surg Br 1993;75(2):249-53.

38. Clement ND, Biant LC, Breusch SJ. Total hip arthroplasty: to cement or not to cement the acetabular socket? A critical review of the literature. Arch Orthop Trauma Surg 2012;132(3):411-27. CrossRef

39. Ranawat CS, Peters LE, Umlas ME. Fixation of the acetabular component. The case for cement. Clin Orthop Relat Res 1997;(344):207-15.

40. Schmalzried TP, Kwong LM, Jasty M, Sedlacek RC, Haire TC, O'Connor DO, Bragdon CR, Kabo JM, Malcolm AJ, Harris WH. The mechanism of loosening of cemented acetabular components in total hip arthroplasty. Analysis of specimens retrieved at autopsy. Clin Orthop Relat Res 1992;(274):60-78.

41. Morscher EW. Cementless total hip arthroplasty. Clin Orthop Relat Res 1983;(181):76-91.
42. Patil N, Lee K, Goodman SB. Porous tantalum in hip and knee reconstructive surgery. J Biomed Mater Res B Appl Biomater 2009;89(1):242-51. CrossRef

43. Meneghini RM, Ford $\mathrm{KS}$, McCollough $\mathrm{CH}$, Hanssen $\mathrm{AD}$, Lewallen DG. Bone remodeling around porous metal cementless acetabular components. J Arthroplasty 2010;25(5):741-7. CrossRef

44. Wasielewski RC, Cooperstein LA, Kruger MP, Rubash HE. Acetabular anatomy and the transacetabular fixation of screws in total hip arthroplasty. J Bone Joint Surg Am 1990;72(4):501-8.

45. Huo MH, Stockton KG, Mont MA, Parvizi J. What's new in total hip arthroplasty. J Bone Joint Surg Am 2010;92(18):295972. CrossRef

46. Jones LC, Hungerford DS. Cement disease. Clin Orthop Relat Res 1987;(225):192-206.

47. Belmont PJ Jr, Powers CC, Beykirch SE, Hopper RH Jr, Engh CA Jr, Engh CA. Results of the anatomic medullary locking total hip arthroplasty at a minimum of twenty years. A concise follow-up of previous reports. J Bone Jt Surg Am 2008;90(7):1524-30. CrossRef

48. Berry DJ, Halasy M. Uncemented acetabular components for arthritis after acetabular fracture. Clin Orthop Relat Res 2002;(405):164-7.

49. Breusch SJ, Malchau H, editors. The Well-Cemented Total Hip Arthroplasty. Theory and Practice. Germany: Springer Medizin Verlag Heidelberg; 2005.

50. Fevang BT, Lie SA, Havelin LI, Engesaeter LB, Furnes O. Improved results of primary total hip replacement. Acta Orthop 2010;81(6):649-59. CrossRef

51. Flivik G, Sanfridsson J, Onnerfalt R, Kesteris U, Ryd L. Migration of the acetabular component: effect of cement pressurization and significance of early radiolucency: a randomized 5-year study using radiostereometry. Acta Orthop 2005;76(2):159-68.

52. Kobayashi S, Terayama K. Factors influencing survival of the socket after primary low-friction arthroplasty of the hip. Arch Orthop Trauma Surg 1993;112(2):56-60.

53. Hallan G, Lie SA, Havelin LI. High wear rates and extensive osteolysis in 3 types of uncemented total hip arthroplasty: a review of the PCA, the Harris Galante and the Profile/TriLock Plus arthroplasties with a minimum of 12 years median follow-up in 96 hips. Acta Orthop 2006;77(4):575-84.

54. Morshed S, Bozic KJ, Ries MD, Malchau H, Colford JM Jr. Comparison of cemented and uncemented fixation in total hip replacement: a meta-analysis. Acta Orthop 2007;78(3):315-26.

55. Bjerkholt $\mathrm{H}, \mathrm{H} ø$ vik $\mathrm{O}$, Reikerås $\mathrm{O}$. Direct comparison of polyethylene wear in cemented and uncemented acetabular cups. J Orthop Traumatol 2010;11(3):155-8. CrossRef

56. Kim YH, Kook HK, Kim JS. Total hip replacement with a cementless acetabular component and a cemented femoral component in patients younger than fifty years of age. J Bone Joint Surg Am 2002;84-A(5):770-4.

57. Kurtz SM, Ochoa JA, White CV, Srivastav S, Cournoyer J. Backside nonconformity and locking restraints affect liner/ shell load transfer mechanisms and relative motion in modular acetabular components for total hip replacement. J Biomech 1998;31(5):431-7.

58. Chawda M, Hucker P, Whitehouse SL, Crawford RW, English $\mathrm{H}$, Donnelly WJ. Comparison of cemented vs uncemented acetabular component positioning using an imageless navigation system. J Arthroplasty 2009;24(8):1170-3. CrossRef 
59. Lewinnek GE, Lewis JL, Tarr R, Compere CL, Zimmerman JR. Dislocations after total hip-replacement arthroplasties. J Bone Joint Surg Am 1978;60(2):217-20.

60. Hailer NP, Garellick G, Karrholm J. Uncemented and cemented primary total hip arthroplasty in the Swedish Hip Arthroplasty Register. Acta Orthop 2010;81(1):34-41. CrossRef

61. Hooper GJ, Rothwell AG, Stringer M, Frampton C. Revision following cemented and uncemented primary total hip replacement: a seven-year analysis from the New Zealand Joint Registry. J Bone Joint Surg Br 2009;91(4):451-8. CrossRef

62. Eskelinen A, Remes V, Helenius I, Pulkkinen P, Nevalainen J, Paavolainen P. Uncemented total hip arthroplasty for primary osteoarthritis in young patients: a mid-to long-term followup study from the Finnish Arthroplasty Register. Acta Orthop 2006;77(1):57-70.

63. Hermida JC, Bergula A, Chen P, Colwell CW Jr, D'Lima DD. Comparison of the wear rates of twenty-eight and thirtytwo-millimeter femoral heads on cross-linked polyethylene acetabular cups in a wear simulator. J Bone Joint Surg Am 2003;85-A(12):2325-31.

64. Bader R, Steinhauser E, Scholz R, Simnacher M, Mittelmeier W. Experimental analysis of neutral, asymmetric and constraint liners for total hip replacement: investigation of range of motion and protection against joint instability. Z Orthop Ihre Grenzgeb 2004;142(5):577-85.
65. Latif AM, Mehats A, Elcocks M, Rushton N, Field RE, Jones E. Pre-clinical studies to validate the MITCH PCR Cup: a flexible and anatomically shaped acetabular component with novel bearing characteristics. J Mater Sci Mater Med 2008;19(4):1729-36.

66. Campbell PA, Wang M, Amstutz HC, Goodman SB. Positive cytokine production in failed metal-on-metal hip replacements. Acta Orthop Scand 2002;73(5):506-12.

67. Willert HG, Buchhorn GH, Fayyazi A, Flury R, Windler $\mathrm{M}$, Köster $\mathrm{G}$, Lohmann $\mathrm{CH}$. Metal-on-metal bearings and hypersensitivity in patients with artificial hip joints. A clinical and histomorphological study. J Bone Joint Surg Am 2005;87(1):28-36.

68. Holzwarth U, Cotogno G. Total Hip Arthroplasty. State of the Art, Challenges and Prospects. Italy: European Commission, Joint Research Centre; 2012.

69. McKellop HA. Bearing surfaces in total hip arthroplasty: state of the art and future developments. Instr Course Lect 2001;50:165-79. 